\title{
THE PASSING OF THE EDITORIAL PENCIL
}

A s some of you already may have recognized from the inside cover, this issue marks the second editorial transition in the brief history of the journal. Latin American Antiquity was founded in 1990, with Prudence M. Rice as editor; in September 1993, she, in turn, passed the mantle to David M. Pendergast. With this issue, it is our great pleasure to accept the responsibility and opportunity of this service, which already has shown itself to be a stimulating challenge.

At its foundation, when then Society for American Archaeology President Jeremy A. Sabloff (1990:1[2]) introduced this publication, he expressed the Executive Board's intent to establish a "firstclass journal" that reaches out to scholars across political and linguistic borders. We believe that our current coeditor arrangement is well suited to meet those goals, and we aim to build on the tireless efforts and impressive successes of the two prior editors toward the establishment of a truly international journal of the highest quality. We have expanded Latin American representation on the journal's editorial committees, and, for the first time, speakers of English, Spanish, and Portuguese are represented on Latin American Antiquity's Board of Editors. We wish to thank those scholars who graciously have agreed to work with us during the next three years on the journal as well as all of the members of the editorial committees who assisted this publication over the past few years.

In what we perceive to be a significant development, we have asked for and received support from the Society to undertake the production of a Spanish Style Guide, which will be published in a forthcoming issue of the journal. We believe this is a necessary step that will facilitate publication in Latin American Antiquity by native Spanish speakers from across Latin America and beyond.

As editors, we are looking to attract and publish articles that are international in scope and character. If ever the notion has been held that Latin American Antiquity was strictly a journal for regional manuscripts, with anything of broader relevance destined for American Antiquity, we wish to dispel it. On the basis of numerous professional conversations, it is clear to us that the former practice, in which select Latin American archaeology articles in English appeared with regularity in American Antiquity, precipitated unnecessary confusion and a residue of bad feeling. With the much-appreciated cooperation of Lynne Goldstein, the new editor of American Antiquity, we can say without equivocation that Latin American Antiquity is now the Society for American Archaeology's outlet for Latin American archaeology and ethnohistory. During our editorial term, we welcome manuscripts, rich in empirical content, that may be largely regional in flavor; we also endeavor to include key selections of broader scope and panregional relevance in every issue.

As you either return from the field with the spark of an idea for a manuscript or finalize your summer writing projects for publication, please be aware that the current subscriber base for Latin American Antiquity is not only greater than most other archaeology journals but larger than the print runs for many edited books. In addition, Latin American Antiquity has a readership that is PanAmerican, perhaps global, in scope. This journal is the only archaeology journal that explicitly serves as a bridge across the Americas. We also currently do not have a manuscript backlog. Papers that are sent to us this fall have the potential to move rapidly to publication in little more than a year.

We realize that you, as readers, subscribers, and authors, have many choices on what to read and where to publish. If we are to encourage your close association with Latin American Antiquity, we 
understand that several pledges and promises are in order. Most importantly, we are committed to getting the journal back on schedule by the end of the year. We have learned that once publication is late, returning to schedule is not easy, since copyediting and printing schedules then must be doubled up (much like the proverbial pig moving through the body of the python). Nevertheless, with the help of Janet Walker (the journal's Managing Editor) and the support of the Society's Executive Board, when you open the journal this December our cover date should once again match your calendar. Please be assured that the manuscript copy for our first three issues was all prepared and submitted in advance of our deadlines, and we are doing all that we can to return Latin American Antiquity to its intended schedule.

We also pledge to review and return your submitted manuscripts with greater speed. Although we promise a decision on all papers in four to six months, our practice to date has been to reach a decision on every manuscript in no more than ninety days. We hope to maintain this shorter time frame for most of the year, although some delays may occur in the summer when so many archaeologists are away from their desks. One of the ways that we have expedited the review process is through the use of electronic mail to query potential manuscript reviewers. If you are interested in reviewing manuscripts for Latin American Antiquity, please contact Gary Feinman by email (gfeinman@ facstaff.wisc.edu) or letter with your email address (providing you have one) and the areas/topics that you are interested in reviewing.

We would like to thank David Pendergast for his bits of sage advice and for easing our transition to editorship. We also acknowledge the work that he did on many of the manuscripts that appear here and in the next three issues. A number of forthcoming papers were fully accepted by David, including a manuscript by one of us (Linda Manzanilla) that is to be published in the forthcoming September issue. This paper was positioned in the publication queue at the time that the recent editorial transition took effect.

In closing, we wish to encourage your suggestions for the journal and recommendations for articles that you would like to write for or read in Latin American Antiquity. If you have a question, idea, or problem, please feel free to contact either of us (for Linda Manzanilla: lmanza@servidor.unam.mx), Managing Editor Janet Walker (janet_walker@saa.org), or the journal's editorial staff in Madison, Wisconsin (latamaq@macc.wisc.edu). We look forward to hearing from you.

Gary M. Feinman and Linda Manzanilla Coeditors 